IAC-20, E7,2,x55609

\title{
Developing and Managing Moon and Mars Settlements in Accordance with International Space Law
}

\author{
Antonino Salmeri* \\ University of Luxembourg, antonino.salmeri@uni.lu
}

\begin{abstract}
* Doctoral Researcher in Space Law at the University of Luxembourg, under the supervision of Prof. Mahulena Hofmann and with the support of the Luxembourg National Research Fund (FNR) (PRIDE17/12251371). Mr. Salmeri is also Lead of the E.A.G.L.E. Action Team on Lunar governance within Space Generation Advisory Council and Governing Member of the International Space University.
\end{abstract}

\begin{abstract}
Despite still being a few decades in the future, the idea of establishing an extra-terrestrial settlement on another celestial body, being it the Moon or Mars, has never been so strong. Moving from the premise that future Moon and Mars settlements shall not take place in a lawless space, this paper addresses the question of how to develop and manage them in accordance with international space law. To this end, it conducts a systematic analysis of the Outer Space Treaty (OST), with the goal of assessing the scope of the freedom to use celestial bodies under international space law. Based on this analysis, and building on the successful experience of the International Space Station, the paper proposes the development of open international settlements made of shared modular facilities. In accordance with the principles of adaptive governance and subsidiarity, the paper argues that the regulation of such settlements should be based on a multi-level framework integrating international recommendations and bilateral arrangements. Under the proposed governance scheme, international recommendations should provide a general framework enabling the development of the settlement, while leaving its management to the mutual agreement of the parties. Finally, the paper presents four essential goals to be achieved by the recommendations and ultimately concludes by arguing that while international cooperation in the development and management of extra-terrestrial settlements is not a legal obligation, it may very well be the only political option that we have to preserve the peaceful uses of outer space.
\end{abstract}

Keywords: International space law, Moon Village, Mars settlement, international cooperation, adaptive governance

\section{Table of Contents}

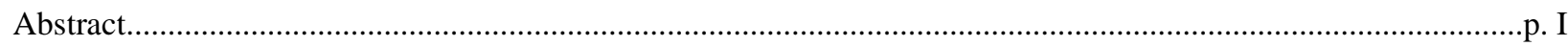

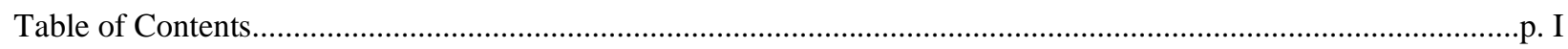

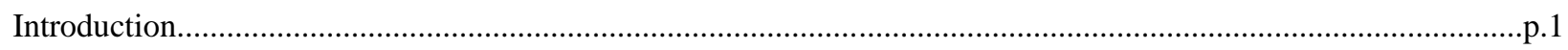

1. The Freedom of Use Celestial Bodies Under International Space Law ............................................................. 2

2. Open Settlements Made of Internationally Shared Modular Facilities............................................................... p.5

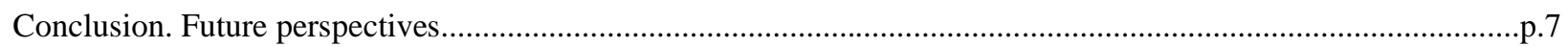

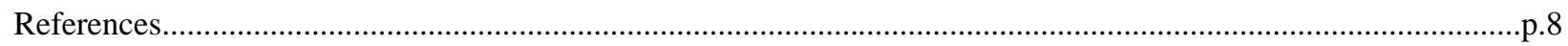




\section{Introduction.}

According to a recent assessment conducted by Bryce Space, there are currently 95 missions to the Moon and 11 missions to Mars planned for the coming decade. ${ }^{1}$ Among these missions, some are meant to lay down the foundations for the establishment of permanent extraterrestrial settlements. Despite still being a few decades in the future, the idea of establishing a human settlement on another celestial body, being it the Moon or Mars, has never been so strong. Supporters of this idea argue that it is the only way to save our species from the inevitable extinction that awaits us should we never leave our planet. $^{2}$ On the other hand, critics of extraterrestrial settlements believe that we should invest our time and resources to make Earth more sustainable, rather than trying to escape it. ${ }^{3}$ Moving from the premise that future Moon and Mars settlements shall not take place in a lawless space, this paper will address the question of how to develop and manage them in accordance with international space law. To this end, it will conduct a systematic analysis of the Outer Space Treaty, ${ }^{4}$ with the goal of assessing the scope of the freedom to use celestial bodies in light of the limitations laid down in international space law. Based on this analysis, the paper will propose the development of open international settlements made of shared modular facilities. Accordingly, the paper will conclude by arguing in favor of enhanced international cooperation and mutual assistance as key drivers in the development and management of extra-terrestrial settlements.

\section{The Freedom of Use Celestial Bodies Under International Space Law}

As is well-known, the OST is considered to be the Magna Charta of space law. ${ }^{5}$ Its provisions have been designed to provide general rules that could be applied to all space activities, ${ }^{6}$ and have successfully governed the exploration and use of outer space over the last 53 years. ${ }^{7}$ To the surprise of non-lawyers, a significant part of this success should be attributed to the various gaps and apparent contradictions of which the OST seems to be full. Rather than impeding the application of the OST, these gaps and contradictions have left sufficient margin for its adaptation to the many facets of space activities. ${ }^{8}$ The establishment of a permanent settlement on another celestial body is a case in point: the OST doesn't provide concrete parameters to draw the line between legitimate use of celestial bodies and their unlawful appropriation. ${ }^{9}$ By virtue of public international law, ${ }^{10}$ such a delicate task must be exercised in accordance with the rules of interpretation provided by Articles 31-33 of the Vienna Convention on the Law of Treaties. ${ }^{11}$ Accordingly, this section will interpret relevant provisions of the OST to assess their impact on the freedom to use celestial bodies for the purpose of developing a permanent human settlement on another celestial body. Needless to say, the starting point of this analysis is Article I OST. This article lays down the foundations of the entire system of international space law, ${ }^{12}$ and is one of the longest and most complex provisions of the OST. In its three paragraphs, Article I OST marks the global relevance of outer space and solemnly declares the freedom to explore and use it, with special emphasis on international cooperation. ${ }^{13}$ Obviously, this article has crucial legal implications on the development of a permanent human settlement on another celestial body. As is well-known, Article I OST provides the legal basis for the freedom to explore and use outer space, including celestial bodies. ${ }^{14}$ Leaving aside the interpretation of "exploration", we will now apply Articles 31-33 VCLT on the meaning of "use". To begin with the literal criteria, it is clear that the term "use" has a broad and general meaning which encompasses a wide range of activities, both economic and non-economic. ${ }^{15}$ More pertinently and with specific reference to physical objects, such are celestial bodies, the term "use" ordinarily includes the unilateral right to take exclusive possess of the object and employ it for any lawful purpose. ${ }^{16}$ Based on this interpretation, we could argue that the freedom to use celestial bodies also include the right to develop a permanent settlement over their territory. However, testing this interpretation against the systematic criteria, we can see that this right is subject to certain limits and conditions, to be found both inside and outside Article I OST itself. ${ }^{17}$ Therefore, to draw the line between legitimate uses and unlawful behaviours, we need to identify and then interpret the meaning of the limits and conditions impacting on the general freedom of use. Already in Article I OST, we can count five "conditions" further specifying the purposes and the modalities for the valid exercise of the freedom to use celestial bodies. ${ }^{18}$ On top of them, Articles II, III, IV and IX OST provide other relevant limitations which will be also taken into account. ${ }^{19}$

\section{Inherent Limits within Article I OST}

The conditions provided by Article I OST are called inherent and are considered to be particularly important because of their collocation within the same article. ${ }^{20}$ To begin with the first one, even before declaring space to 
be free for use and exploration, Article I (1) OST provides that space activities "shall be carried out for the benefit and in the interests of all countries, irrespective of their degree of economic or scientific development, and shall be the province of all mankind". ${ }^{21}$ Concerning the first part of the provision, given the broadness and ambiguity of its wording, it is worth looking at subsequent State practice to shred light over its legal meaning. ${ }^{22}$ In 1996, the General Assembly of the United Nations issued a Declaration for guiding the implementation of the principle of benefit sharing. ${ }^{23}$ The 1996 Space Benefit Declaration makes very clear that there is no general duty to share the various benefits of space activities. ${ }^{24}$ At the same time, States are encouraged to do so through cooperation, mutual assistance and inclusiveness. ${ }^{25}$ If we look at State practice, we will often find that there are many ways to share the benefits of space activities. For instance, let's consider the Apollo program. Clearly, that exercise of the freedom to explore and use the Moon was mostly beneficial for one country, the United States, and certainly did not "benefit" its political adversary, the Soviet Union. At the same time, the experiments and activities conducted by the Apollo astronauts led to unprecedented scientific discoveries on our closest neighbour and to significant developments in space exploration. ${ }^{26}$ These benefits have been shared by the US even with the Soviet Union and clearly benefited of all countries. Further, if we look at the dynamics of the space industry, every year telecommunication companies earn billions of dollars by "using" space for satellite communications. ${ }^{27}$ While no licensing State has ever asked these companies to share a cent of their profits, the technology at the core of satellite communications has also saved thousands of people lost at sea, thus benefiting all humankind..$^{28}$ On a similar line of reasoning, the GPS program may have begun as a military program of the US Government, but it has also created significant benefits for the space industry and today is even used for free by billions of individuals on the planet. ${ }^{29}$ Accordingly, while State practice shows a flexible interpretation of the obligation to share the benefits of space activities, the global trend is very much in favour of sharing benefits rather than not. ${ }^{30}$ Concerning the "province of all mankind", its literal interpretation is understood to establish outer space and celestial bodies as res communes omnium, i.e. "goods that belong to everyone". ${ }^{31}$ Notably, such interpretation is further reinforced by a systematic reading of the treaty, especially in light of both the prohibition of national appropriation under Article II OST and the principle of due regard under Article IX OST, thus providing the legal basis for considering outer space as a global common. ${ }^{32}$ For the purpose of our analysis, we can therefore draw two provisional conclusions. First, States would not be obliged to immediately or directly distribute the benefits arising from the establishment of an extra-terrestrial settlement. ${ }^{33}$ At the same time, in accordance with the status of space as global common, the features of these settlements shall prevent any monopolist behaviour in the use of celestial bodies. ${ }^{34}$ Moving to the second inherent condition imposed on the freedom to use celestial bodies, we find the principle of non-discrimination. ${ }^{35}$ Pursuant to the literal and systematic criteria, we can interpret the general meaning of this provision as reinforcing the legal status of space as a shared environment. ${ }^{36}$ Notably, this limitation should be read in conjunction with the third condition laid down in Article I OST, which further complements the principle of non-discrimination with the principle of equality. ${ }^{37}$ Applying the literal criterion, we find that "equality" can be understood as either formal or substantive, depending on the context. Considering the drafting history of the OST, we can conclude in favor of substantive equality. ${ }^{38}$ From subsequent State practice, we find that the principle of equality has been mostly implemented through international cooperation and capacity building. ${ }^{39}$ Accordingly, the principle of substantive equality requires the development of a "level-playing field" whereby all States become capable of conducting their own space activities by learning from, and participating to, the activities of the others. From these two limitations we can derive two findings. First, in accordance with the principle of nondiscrimination, States developing an extra-terrestrial settlement should not grant unilateral privileges for accessing or using it to a limited group of countries. Second, in compliance with the principle of equality, the development of an extra-terrestrial settlement should be an inclusive process open to the contributions of international partners. Moving to the fourth condition within Article I OST, celestial bodies shall be used "in accordance with international law". ${ }^{40}$ The interpretation of this clause is unanimous in establishing that outer space is not subtracted ipso facto to the application of public international law. ${ }^{41}$ This rule will be repeated, reinforced and expanded in Article III OST, ${ }^{42}$ which we will consider later in this analysis, but for now we can conclude that celestial bodies shall not be used in a manner or for purposes that are inconsistent with international law. Fifth and final, Article I (2) OST requires that "there shall be free access to all areas of 
celestial bodies". ${ }^{43}$ At first glance, this provision seems to be quite straightforward in excluding any sort of exclusive territorial control over celestial bodies. However, such literal interpretation seems heading towards manifestly unreasonable results, since it would practically outlaw every stable activity on the surface of celestial bodies. ${ }^{44}$ Therefore, pursuant to a systematic reading of the OST, we can argue that the right of "free access to all areas of celestial bodies" needs to be properly balanced against the right of using them as provided by other Articles of the treaty. ${ }^{45}$ For instance, according to Article XII OST all stations built on another celestial body shall be open to representatives of other OST Parties "on a basis of reciprocity" ${ }^{46}$ As an obvious pre-requisite for this obligation, it is clear that Article XII OST implicitly recognizes the right of building such stations in the first place. ${ }^{47}$ Since a literal interpretation of Article I (2) OST would jeopardize the legal meaning of Article XII OST, we can conclude that the scope of the principle of free access is limited to natural areas of celestial bodies, with the significant exclusion of human-made stations. Notably, this conclusion is further confirmed by Article VIII OST, ${ }^{48}$ according to which States shall retain jurisdiction and control over their registered space objects, ${ }^{49}$ including those built on the surface of another celestial body. ${ }^{50}$ Therefore, for the purpose of our analysis, we can conclude that States can legitimately use the territory of celestial bodies to build artificial installations composing a settlement upon them, but cannot instead restrict access to the natural territory surrounding them.

\section{Further Limits under Articles II, III, IV and IX OST}

In addition to the conditions laid down in Article I OST, the right to use celestial bodies needs to be measured first against Article II OST. This provision establishes the non-appropriation of outer space and celestial bodies, ${ }^{51}$ a principle of cardinal importance within space law. ${ }^{52}$ Article II OST safeguards the legal status of outer space as global common and for this reason it is considered by some as a structural norm protecting the whole system of space law. ${ }^{53}$ Article II OST prevents States to use space in order to further extend their territorial influence, ${ }^{54}$ and in this way ensures that this domain remains truly free for exploration and use by all States. Especially in light of this latter argument, there is a risk that nationally developed extra-terrestrial settlements could, in time, ultimately reach the point of violating, at least de facto, Article II OST ${ }^{55}$ While some concerns related to potential monopolist behaviours on celestial bodies are certainly legitimate, following the principle of adaptive governance we should not outlaw planned activities based on potential violations that may occur in the future. On the contrary, given the very primitive structure foreseeable for early extra-terrestrial settlements, we can safely argue that their development would not necessarily infringe Article II OST. Following the same methodology applied for the inherent limits, this conclusion can be confirmed through the application of both the literal and systematic criteria of interpretation. First, it should be noted that in forbidding appropriation "by means of use or occupation" ${ }^{56}$ Article II OST literally moves from the legality of those activities under international space law. ${ }^{57}$ Quite intuitively, if the use or occupation of outer space and celestial bodies were to be unlawful activities per se, there would have been no need to prevent them from serving as potential means for national appropriation. On the contrary, and for obvious reasons of internal coherence within the treaty, Article II OST moves from the premise that use and occupation of outer space and celestial bodies are lawful activities under Article I OST. This conclusion is further reinforced by looking at Articles IV (2) and XII OST. Under the first provision, celestial bodies shall be used for exclusively peaceful purposes. ${ }^{58}$ Significantly, in forbidding the establishment of military bases on celestial bodies, Article IV (2) OST reinforces the right to develop territorial facilities realized for exclusively peaceful purposes. ${ }^{59}$ Conversely, under Article XII OST States are entitled to establish their artificial stations and installations over the territory of celestial bodies, ${ }^{60}$ thus confirming that their occupation is indeed lawful under the OST. ${ }^{61}$ Accordingly, we can interpret Article II OST as excluding national appropriation from both the legitimate purposes and the legal effects related to the use or occupation of outer space and celestial bodies. ${ }^{62}$ Based on the above, we can conclude that States can in fact use the territory of celestial bodies for developing extra-terrestrial settlements without infringing, at least in the early stages, Article II OST. Moving to Article III OST, as anticipated, this provision builds on Article I OST to restate the necessary respect for international law in conducting space activities. ${ }^{63}$ However, when compared to Article I OST, this article further adds that space activities shall be conducted "in the interest of maintaining international peace and security". ${ }^{64}$ Literally, this clause reminds of the functions devolved to the UN Security Council under Article $24 \mathrm{UN}$ Charter. ${ }^{65}$ Systematically, Article III OST reinforces the fundamental principle of the peaceful uses of space by reminding States that activities in space cannot be 
exercised at the expense of international peace and security on Earth. ${ }^{66}$ Further, as per the last clause of the article, space activities should instead promote international cooperation and understanding among States. ${ }^{67}$ From the limitations laid down in Article III OST we can conclude that extra-terrestrial settlements cannot possess features that would threaten international peace and security on Earth. Such argument naturally brings us to Article IV (2) OST, which states that celestial bodies shall be used exclusively for peaceful purposes. ${ }^{68}$ Literally speaking, the use of the term "exclusively" seems to outlaw both military and aggressive acts on the territory of another celestial body. ${ }^{69}$ Systematically, Article IV (2) OST is closely related with Articles III and IX OST, insofar as limiting the use of celestial bodies for exclusively peaceful purposes supports international peace and security on Earth and international cooperation in space. For the purpose of our analysis, it means that States cannot exercise traditional coercive measures for developing and managing extra-terrestrial settlements. ${ }^{70}$ The last limit that will be considered as part of this analysis is the principle of due regard under Article IX OST. In international law, the term "due regard" refers to the performance of an act with a certain standard of care, attention or observance. ${ }^{71}$ It was introduced for the first time in 1944, as part of Article 3 of the Chicago Convention, and was later included also within Article 87 (2) of the United Nations Convention on the Law of the Sea. ${ }^{72}$ In a recent case from the International Tribunal for the Law of the Sea, this expression appeared for the first time in a decision from an international court. ${ }^{73}$ There, it is defined by one of the parties as the obligation of States, when exercising their freedoms, to consider the interests of other States and refrain from interfering with other States exercising the same freedoms. ${ }^{74}$ Under international space law, the principle of due regard functions as a limitation to the freedom of exploration and use of outer space provided for in Article I (2) OST. ${ }^{75}$ Similarly to what has been argued in the Norstar case, paying due regard to the corresponding interests of other States in exercising the freedom to explore and use outer space means that a State is only entitled to undertake activities that would not threaten those of other States. ${ }^{76}$ Notably, the principle of due regard embodies a mandatory obligation under international space law. As mentioned, it imposes a direct limitation on the freedom to explore and use space and should as such be taken into serious consideration, especially when planning a particularly invasive activity like building an extra-terrestrial settlement. In this respect, first bits of available State practice on the matter show particular consideration for the principle of due regard. For instance, the U.S. Government has recently released a set of Principles for a Safe, Prosperous and Peaceful Future ${ }^{77}$ which are intended to implement the Outer Space Treaty in the development and execution of the Artemis Program. ${ }^{78}$ Among these principles, one is dedicated to "deconfliction of activities" and explicitly mentions the importance of the principle of due regard. In the interpretation proposed by the U.S. Government, this principle requires "notification and coordination between partner nations" to respect reciprocal areas of operation, with the ultimate goal of preventing harmful interference. ${ }^{79}$ For the purpose of our analysis, we can therefore conclude that paying an appropriate degree of due regard will play a crucial role in favor or against the lawfulness of a given extra-terrestrial settlement.

\section{Pushing International Space Law to the Limit}

At the end of our systematic interpretation, we have reached the following conclusions. According to Articles I, VIII and XII OST, States have the right to develop human settlements on other celestial bodies. At the same time, this right is only valid insofar as it is exercised in light of the obligations stemming from Articles I, II, IV and IX OST. Ultimately, in light of the invasive nature of this endeavor, it seems that exercising the right to use a celestial body for developing a permanent settlement over its territory will push the current system of international space law to its very limits. Above all, after balancing Article I OST with its internal and external limitations, we are left with a high potential for abuses, conflict and disputes. To reduce this risk and conversely raise the level of compliance with international space law, the next section will propose the development of open settlements made of internationally shared modular facilities.

\section{Open Settlements made of Internationally Shared Modular Facilities}

The solution proposed in this paper is based on the principles of cooperation and mutual assistance as key drivers for peacefully exercising the right to use celestial bodies. As is well-known, international cooperation is among the key principles of space activities and perhaps the strongest guarantee of their peaceful purposes. When States cooperate and assist each other, the potential for conflict and abuses is reduced to the minimum. Accordingly, international cooperation in the peaceful uses of space enhances the level of compliance with 
Articles I, II, III and IV OST. Inter alia, international cooperation extends the range of beneficiaries of space activities, prevents non-discrimination, fosters equality and is a key component international law. ${ }^{80}$ If States would genuinely be guided by the principle of cooperation and mutual assistance in the development of extra-terrestrial settlements, then compliance with the main rules of international space law would come quite naturally. Surely, international cooperation is not a legal obligation. ${ }^{81}$ As clarified by the 1996 Space Benefits Declaration, international cooperation is rather based on the free determination of fair, equitable and mutually acceptable contractual terms. ${ }^{82}$ At the same time, the special emphasis that international space law puts on preserving celestial bodies from typical sovereign behaviours may justify the legal need for a high level of international cooperation in their use. Evidently, a fully cooperative approach in the development of international settlements constitutes a strong safeguard against the national appropriation of celestial bodies and a solid guarantee of their exclusively peaceful uses ${ }^{83} \mathrm{As}$ anticipated, the solution presented in this section is based on the development of settlements which should be open to the contributions of international partners and composed of modular facilities to be shared with all interested actors.

\section{Hand in Hand with International Space Law}

Establishing open settlements made of internationally shared modular facilities would implement Articles I, III, IV, IX and XII OST without likely violating any other article from the treaty. First, such settlements would evidently be developed for the benefit and in the interests of all countries, because their facilities would be at the disposal of the international community. These settlements would also avoid discriminations of any kind and truly achieve equality in the use of celestial bodies, because they would welcome contributions from international players at all levels of financial and technological development. The open structure and the international character would also clearly contribute to "maintaining international peace and security and promoting international cooperation and understanding", as mandated by Article III OST for the exploration and use of space. On the same line of reasoning, these features would also ensure the use of celestial bodies exclusively for peaceful purposes, in compliance with Article IV OST. Finally, this type of settlements would fully implement the principles of cooperation and mutual assistance as enshrined in Article IX (1) OST, inherently paying due regard to the corresponding interests of all States Parties to the OST. On top of this, considering that sustainability is among the key drivers for upcoming lunar activities, developing open settlements made of internationally shared modular facilities would also be in line with many of the UN Guidelines for the Long-Term Sustainability of Outer Space Activities. ${ }^{84}$ To mention some, Guideline C. 1 explicitly states that international cooperation may include the "exchange of technology and equipment for space activities" ${ }^{85}$ as in the case of a settlement made of internationally shared modular facilities. Such settlement would also implement Guidelines D.1.3 and D1.5, as its structure would promote the development of technologies "maximizing the reusability or repurposing of space assets" 86 while also "encouraging the participation of developing countries". ${ }^{87}$ In this respect, and in accordance with Guideline C.3.3, ${ }^{88}$ an open settlement welcoming contributions from all States would notably "avoid unnecessary duplication of function and efforts" in capacity building. Not by chance, the development of the proposed settlement would give significant consideration to the needs and interests of developing countries. Through this model, these countries would get a unique opportunity to overcome the technological and financial barriers connected to the autonomous development of an extraterrestrial settlement. Under the proposed settlement, developing countries would be able to benefit from, and add their own contributions to, an evolving settlement developed in partnership with space-faring nations. Speaking at the "Sustainability Summit" organized by Secure World Foundation, NASA Administrator Jim Bridenstine stressed the importance of democratizing access to other celestial bodies, and the Moon in particular. ${ }^{89}$ As a mean to this end, NASA is strongly pushing for involving the private sector into the core of lunar operations. Through the participation of the private sector, NASA hopes to reduce the costs traditionally associated with space exploration and also break the political barriers that may stand in the way of global cooperation..$^{90}$ Accordingly, at the same event, Bridenstine announced a solicitation open to the participation of all international actors to provide proposals for the collection of space resources. ${ }^{91}$ The international character of this solicitation may hopefully suggest a commitment towards an open approach for lunar activities: "anybody can participate at whatever level they can participate.". 92 On a very positive note, these words align perfectly with ESA's concept of the Moon Village as "an environment where both international cooperation and the commercialization of 
space can thrive". ${ }^{93}$ Ultimately, there seems to be a shared understanding that developing an extra-terrestrial settlement should be a multi-lateral and multistakeholder effort. ${ }^{94}$ In turn, this would ensure full compliance with international space law while also reducing the costs and increasing our technical chances to be successful.

\section{Governance System}

Given the high costs of international cooperation, the key to the successful implementation of the solution proposed in this paper lies in the development of a flexible but also effective governance system. Learning from the experience of the International Space Station, ${ }^{95}$ it seems that the regulation of extra-terrestrial settlements should result from a combination of national and international sources. In accordance with the principle of adaptive governance, ${ }^{96}$ international recommendations should provide a general framework enabling the development of the settlement, while leaving its management to the mutual agreement of the parties. Ultimately, the role of these international recommendations would be similar to the one proposed by NASA for the Artemis Principles within the Artemis Program: providing solid foundations for the adaptive regulation of the settlement. To this end, the proposed recommendations should address the following topics. First, they should recognize the right of all actors to access and use extra-terrestrial settlements in accordance with international law. To achieve this goal, the recommendations should further promote the development of global standards and interoperable infrastructure. Second, the recommendations should enable the development of national registration practices for activities on another celestial body and coordinate their international recognition to ensure due regard and avoid harmful interference. Third, the recommendations should provide a shared ground for the adoption of sustainable practices on space resources, heritage protection and information sharing. Fourth and final, the recommendations should promote the development of mutually agreed liability waivers and suggest primary recourse to the Permanent Court of Arbitration for the peaceful resolution of disputes. To be sure, these prepositions are just a starting point for discussion, and the actual content of the recommendations will be addressed in a subsequent publication.

\section{Conclusion}

This paper started with the question of how to develop and manage extra-terrestrial settlements in accordance with international space law. To answer this question, it conducted a systematic analysis of the Outer Space Treaty (OST), with the goal of assessing the scope of the freedom to use celestial bodies under international space law. Based on this analysis, and building on the successful experience of the International Space Station, the paper argued in favor of developing open international settlements made of shared modular facilities. In accordance with the principles of adaptive governance and subsidiarity, the paper proposed that the regulation of such settlements should be based on a multi-level framework integrating international recommendations and bilateral arrangements. Under this governance scheme, international recommendations should provide a general framework enabling the development of incremental regulation by the involved parties. Above all, the recommendations should ensure the following elements. First, they should recognize the right to openly access and use extra-terrestrial settlements, and foster the adoption of interoperable infrastructure. Second, the recommendations should ensure international coordination through the promotion and coordination of national registration practices for activities on another celestial body. Third, the recommendations should form a shared ground for enabling sustainable practices on space resources utilization, heritage protection and sharing of information. Fourth and finally, the recommendations should reduce the potential for conflict by promoting the use of liability waivers and recourse to arbitration. Obviously, the way of international cooperation does not come without costs, especially in terms of time, and thus some actors may be inclined to prefer national or regional approaches. Surely, international cooperation in the development of extra-terrestrial settlements is not a legal obligation. However, given the high stakes involved, it may very well be the only political option that we have to preserve the peaceful uses of space. 


\section{References}

${ }^{1}$ Bryce Space, Projected Exploration Missions (2020-2030), available at https://brycetech.com/reports (accessed October 2020).

${ }^{2}$ Elon Musk, Making Humans a Multi-Planetary Species, 5 (2) New Space 46-50 (2017).

${ }^{3}$ James S.J. Schwartz, Prioritizing scientific exploration: A comparison of the ethical justifications for space development and for space science, 30 Space Policy 202-208 (2014).

${ }^{4}$ Treaty on Principles Governing the Activities of States in the Exploration and Use of Outer Space, Including the Moon and Other Celestial Bodies, entered into force Oct. 10, 1967, 18 U.S.T. 2410, 610 U.N.T.S. 205 [Hereinafter: "OST"]

${ }^{5}$ P. P. C. HAANAPPEL, THE LAW AND POLICY OF AIR SPACE AND OUTER SPACE. A COMPARATIVE APPROACH 9 (2003).

${ }^{6}$ Stephan Hobe, Historical Background of the Outer Space Treaty, in COLOGNE COMMENTARY ON SPACE LAW: VOL. 114 (Stephan Hobe, Bernhard Schmidt-Tedd \& KaiUwe Schrogl eds., 2009).

${ }^{7}$ As stated in the "Declaration on the fiftieth anniversary of the Treaty on Principles Governing the Activities of States in the Exploration and Use of Outer Space, including the Moon and Other Celestial Bodies." U.N. Doc. A/RES/72/78 (29 Dec. 2017).

${ }^{8}$ P.J. Blount, Innovating the Law: Fifty Years of the Outer Space Treaty, in INNOVATION IN OUTER SPACE: INTERNATIONAL AND AFRICAN LEGAL PERSPECTIVES 41 (Mahulena Hofmann \& P.J. Blount eds., 2018).

9 P.J. Blount, Outer Space and International Geography: Article II and the Shape of the Global Order, 52 (2) New England Law Review 103 (2018).

10 Antonino Salmeri, The Regulation of Space Resources Activities Between National And International Law, 43 (1) Journal of Space Law 60-84 (2019).

${ }^{11}$ Vienna Convention on the Law of Treaties, entered into force Jan. 27, 1980, 1155 U.N.T.S. 331 [hereinafter: "VCLT"] 12 MAHULENA HOFMANN \& TANJA MASSONZWAAN, INTRODUCTION TO SPACE LAW 17 (2019)

${ }^{13}$ Article I OST, supra note 4.

${ }^{14}$ Stephen Gorove, Freedom of Exploration and Use in the Outer Space Treaty: a Textual Analysis and Interpretation, 1 Journal Of International Law And Policy 100 (1971).

${ }^{15}$ Use, in MERRIAM-WEBSTER DICTIONARY, available at https://www.merriam-webster.com/dictionary/use (accessed September 2020)

${ }^{16}$ Ibidem.

17 Stephan Hobe, Article I of the Outer Space Treaty, in COLOGNE COMMENTARY ON SPACE LAW: VOL. $136-$ 39 (Stephan Hobe, Bernhard Schmidt-Tedd \& Kai-Uwe Schrogl eds., 2009). See also: Gorove, supra note 14 at 18; Ram Jakhu, Legal Issues Relating to the Global Public Interest in Outer Space, 32 Journal of Space Law 31 (2006).

${ }^{18}$ Hobe, supra note 17 at $36-38$.

${ }^{19} I d$. at 39.

${ }^{20} \mathrm{Id}$. at 36.

${ }^{21}$ Article I OST, supra note 4.
${ }^{22}$ Hobe, supra note 17 at 38.

${ }^{23}$ Declaration on International Cooperation in the Exploration and Use of Outer Space for the Benefit and in the Interest of All States, Taking into Particular Account the Needs of Developing Countries, U.N. Doc. A/RES/51/122 (13th December 1996) [hereinafter: "Space Benefit Declaration"]

${ }^{24}$ Stephan Hobe \& Fabio Tronchetti, Free Determination of Cooperation, in COLOGNE COMMENTARY ON SPACE LAW: VOL. 3 333-336 (Stephan Hobe, Bernhard SchmidtTedd \& Kai-Uwe Schrogl eds., 2009).

${ }^{25}$ Paragraphs 3 \& 5 Space Benefit Declaration, supra note 21. ${ }^{26}$ Lyndon B. Johnson Space Center, Benefits from Apollo: Giant Leaps in Technology, in NASA FACTS (2004). Available at: https://www.nasa.gov/sites/default/files/80660main_ApolloF

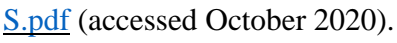

${ }^{27}$ For a detailed analysis of the New Space economy see Marco Ferrazzani, The Development of a New Space Economy and of Mega Constellations, in INNOVATION IN OUTER SPACE: INTERNATIONAL AND AFRICAN LEGAL PERSPECTIVES 93-104 (Mahulena Hofmann \& P.J. Blount eds., 2018).

${ }^{28}$ Hobe, supra note 17 at 41 . For a comprehensive overview of the evolution of the satellite industry and how it benefited humankind, see ANDREW J. BUTRICA, BEYOND THE IONOSPHERE: FIFTY YEARS OF SATELLITE COMMUNICATION (1997).

29 RTI International, ECONOMIC BENEFITS OF THE GLOBAL POSITIONING SYSTEM (GPS) ES 1-4 (2019).

${ }^{30} \mathrm{Jim}$ Brindestine, Life on Earth is Better Because of NASA, 25th September 2020. Available at: https://blogs.nasa.gov/bridenstine/2020/09/25/life-on-earthis-better-because-of-nasa/ (accessed October 2020).

31 BIN CHENG, STUDIES IN INTERNATIONAL SPACE LAW 229-230 (2004). See also Hobe, supra note 17 at 30.

32 Frans Von Der Dunk, International Space Law, in HANDBOOK OF SPACE LAW 55-60 (Frans Von Der Dunk $\&$ Fabio Tronchetti eds., 2015).

33 Fabio Tronchetti, Legal Aspects of Space Resources Utilization, in HANDBOOK OF SPACE LAW 781 (Frans Von Der Dunk \& Fabio Tronchetti eds., 2015).

${ }^{34}$ Hobe, supra note 17 at 41; Von Der Dunk, supra note 29.

${ }^{35}$ Article I OST, supra note 4.

${ }^{36}$ Hobe, supra note 17 at 33.

${ }^{37}$ Article I OST, supra note 4.

${ }^{38}$ Hobe, supra note 17 at 30 . Significantly, the Soviet camp insisted to include it as a necessary mean to foster international cooperation, proposing to adopt it as a "most favored nation" clause. This clause is a legal obligation part of the regime of the World Trade Organization, according to which every WTO member has to extend the same privileges and immunities granted to one country to all WTO members.

${ }^{39}$ Hobe, supra note 17 at $38-40$.

${ }^{40}$ Article I OST, supra note 4.

${ }^{41}$ Cheng, supra note 31 at 228.

${ }^{42}$ Hofmann \& Masson-Zwaan, supra note 12.

${ }^{43}$ Article I OST, supra note 4. 
44 Philippe De Man, Exclusive Use in An Inclusive Environment: The Meaning of The Non-Appropriation Principle For Space Resource Exploitation 417 (2016).

${ }^{45}$ Cheng, supra note 31 at 401.

${ }^{46}$ Article XII OST, supra note 4. For a closer look at Article $\mathrm{XI}$, see Cheng, supra note 31 at 248-251.

${ }^{47}$ Cheng, supra note 31 at 402.

${ }^{48}$ Cheng, supra note 31 at 400.

${ }^{49}$ Article VIII OST, supra note 4.

${ }^{50}$ Cheng, supra note 30 at 502-504.

${ }^{51}$ Article II OST, supra note 4.

${ }^{52}$ Hofmann \& Masson-Zwaan, supra note 12 at 18.

${ }^{53}$ Fabio Tronchetti, The Non-Appropriation Principle Under Attack: Using Article II of The Outer Space Treaty In Its Defense, Proceedings of the 50th Colloquium of the Law of Outer Space 526-536 (2008).

${ }^{54}$ Blount, supra note 9.

${ }^{55}$ Cheng, supra note 31 at 400-401.

${ }^{56}$ Article II OST, supra note 4.

${ }^{57}$ Blount, supra note at 102-103.

${ }^{58}$ Article IV OST, supra note 4.

${ }^{59}$ Hofmann \& Masson-Zwaan, supra note 12 at 19.

${ }^{60}$ Article XII OST, supra note 4.

${ }^{61}$ Cheng, supra note 31 at 401-402; Blount, supra note at 102103.

${ }^{62}$ The same conclusion can be found, with respect to space resources, in Mahulena Hofmann, Space Resources: Regulatory Aspects, in INNOVATION IN OUTER SPACE: INTERNATIONAL AND AFRICAN LEGAL PERSPECTIVES 202-203 (Mahulena Hofmann \& P.J. Blount eds., 2018).

${ }^{63}$ Hofmann \& Masson-Zwaan, supra note 12 at 17.

${ }^{64}$ Article III OST, supra note 4.

${ }^{65}$ U.N. CHARTER.

66 Olivier Ribbelink, Article III OST, in COLOGNE COMMENTARY ON SPACE LAW: VOL. 1 66-67 (Stephan Hobe, Bernhard Schmidt-Tedd \& Kai-Uwe Schrogl eds., 2009).

${ }^{67}$ Article III OST, supra note 4.

68 Article IV OST, supra note 4.

${ }^{69}$ Fabio Tronchetti, Legal Aspects of the Military Uses of Space, in HANDBOOK OF SPACE LAW 338-341 (Frans Von Der Dunk \& Fabio Tronchetti eds., 2015); Hofmann \& Masson-Zwaan, supra note 12 at 19.

${ }^{70}$ Tronchetti, supra note 68 at 340.

71 Sergio Marchisio, Article IX OST, in COLOGNE COMMENTARY ON SPACE LAW: VOL. 1 175-176 (Stephan Hobe, Bernhard Schmidt-Tedd \& Kai-Uwe Schrogl eds., 2009).

${ }^{72}$ Ibidem.

${ }^{73}$ The M/V 'Norstar' case, Panama v. Italy, 10 April 2019, par. 199-ff.

${ }^{74}$ Ibidem.

${ }^{75}$ Hobe, supra note 17 at 39-40.

${ }^{76}$ Marchisio, supra note 70.
77 Principles for a Safe, Peaceful and Prosperous Future. Available at https://www.nasa.gov/specials/artemisaccords/index.html (accessed October 2020).

${ }^{78} \mathrm{Jim}$ Bridenstine, Artemis Is Our Future, 23th July 2019. Available

https://blogs.nasa.gov/bridenstine/2019/07/23/artemis-is-ourfuture/ (accessed October 2020)

${ }^{79}$ Artemis Principles, supra note 76.

${ }^{80}$ Tronchetti, supra note 33 at 781-782.

${ }^{81}$ Hobe \& Tronchetti, supra note 24.

${ }^{82}$ Space Benefit Declaration paragraph 2, supra note 23.

${ }^{83}$ Tronchetti, supra note 33 at 781-782.

${ }^{84}$ Guidelines for the Long Term Sustainability of Outer Space Activities, U.N. Doc. A/74/20, Annex II (20th August 2020) [Hereinafter: "LTS Guidelines"]

${ }^{85}$ LTS Guideline C.1, supra note 84.

${ }^{86}$ LTS Guideline D.1.3, supra note 84.

${ }^{87}$ LTS Guideline D.1.5, supra note 84.

${ }^{88}$ LTS Guideline C.3.3, supra note 84.

${ }^{89}$ Jeff Foust, NASA Offers to Buy Lunarr Samples to Set Space Resources Precedent, 10th September 2020. Available at: https://spacenews.com/nasa-offers-to-buy-lunar-samples-toset-space-resources-precedent/ (accessed October 2020)

${ }^{90} \mathrm{Jim}$ Bridenstine, Funding a New Era of Space Exploration, Science and Discovery, 11 March 2019. Available at: https://blogs.nasa.gov/bridenstine/2019/03/11/funding-a-newera-of-exploration-science-and-discovery/ (accessed October 2020).

91 Jim Brindestine, Space Resources Are the Key to Safe and Sustainable Lunar Exploration, $10^{\text {th }}$ September 2020. Available

https://blogs.nasa.gov/bridenstine/2020/09/10/space-

resources-are-the-key-to-safe-and-sustainable-lunar-

exploration/

${ }^{92}$ Foust, supra note 89.

93 Tom Whipple, Space Chief Sets His Sights on European Moon Village (rocket salad optional), THE TIMES (June $20^{\text {th }}$ 2015).

94 Jim Brindestine, Space Exploration Trascends All Terrestrial Borders, 14th July 2020. Available at: https://blogs.nasa.gov/bridenstine/2020/07/14/space-

exploration-transcends-all-terrestrial-borders/ (accessed October 2020).

${ }^{95}$ Masahiko Fukushima, Legal analysis of the International Space Station (ISS) programme using the concept of “legalisation', 24 Space Policy 33-41 (2008).

${ }^{96}$ The principle of adaptive governance has been at the core of the "Building Blocks for the Development of an International Framework for Space Resources Activities" published on the $12^{\text {th }}$ of November 2019 by The Hague International Space Resources Governance Working Group. Available at: https://www.universiteitleiden.nl/binaries/content/assets/recht sgeleerdheid/instituut-voor-publiekrecht/lucht--enruimterecht/space-resources/bb-thissrwg--cover.pdf (accessed October 2020) 